\title{
Minbiziaren aurkako CAR-T zelulen bidezko immunoterapia
}

(CAR-T cell immunotherapy against cancer)

\author{
Patricia Garcia-Gallastegi*1, Maite Mugica Basauri², \\ Olatz Crende Arruabarrena ${ }^{2}$ \\ ${ }^{1}$ Zelulen Biologia eta Histologia Saila, Medikuntza eta Erizaintza Fakultatea, (UPV/EHU) \\ ${ }^{2}$ Zelulen Biologia eta Histologia Saila, Farmazia Fakultatea (UPV/EHU)
}

LABURPENA: Azkenengo urteotan immunoterapia minbiziari aurre egiteko estrategia baliagarria bihurtu da. Terapia ezagunenetako bati CAR-T deritzo. Tratamendu honetan, gaixoaren $\mathrm{T}$ linfozitoak atera eta laborategian aldatu egiten dira tumorearen aurkako ekintza hobetzeko, «sentsore» mota bat jarrita haren gainazalean (CAR errezeptorea). Horrela, pazienteari berriro linfozito eraldatuak sartzen zaizkio, hauek tumore-zelulak bilatu, ezagutu eta erasotzeko. Berrikuspen honetan, CAR errezeptoreen egitura, sortzeko era eta terapiaren efektu desiragaitzak azalduko ditugu. Azkenik, CAR-T immunoterapia odoleko hainbat tumoretan eraginkorra dela frogatu da, bai eta tumore solido mota batzuetan ere.

HITZ GAKOAK: CAR-T, Minbizia, Immunoterapia.

ABSTRACT: The last years immunotherapy has become a useful strategy in the fight against cancer. One of the most popular therapies is called CAR-T. In this treatment, the patient's $T$ lymphocytes are removed and modified in the laboratory to enhance the action against the tumour by placing a type of "sensor" on its surface (CAR receptor). Thus, the patient is re-introduced with the transformed lymphocytes, which search for, recognize, and attack tumour cells. In this review, we will explain the structure, mode of generation, and adverse effects of CAR receptors on therapy. Finally, CAR-T immunotherapy has been shown to be effective in several blood tumours, as well as in certain types of solid tumors.

KEYWORDS: CAR-T, Cancer, Immunotherapy.

* Harremanetan jartzeko / Corresponding author: Patricia Garcia-Gallastegi. Zelulen Biologia eta Histologia Saila, Medikuntza eta Erizaintza Fakultatea, UPV/EHU. Sarriena auzoa z/g, 48940, Leioa, Bizkaia. - patricia.garcia@ehu.eus - https://orcid. org/0000-0002-5140-3390

Nola aipatu / How to cite: Garcia-Gallastegi, Patricia; Mugica Basauri, Maite; Crende Arruabarrena, Olatz (2021). «Minbiziaren aurkako CAR-T zelulen bidezko immunoterapia». Ekaia, 40, 2021, 77-88. (https://doi.org/10.1387/ekaia.21946).

Jasotze-data: 2020, abuztuak 9; Onartze-data: 2021, urtarrilak 7.

ISSN 0214-9753 - eISSN 2444-3581 / (c) 2021 UPV/EHU

(c) (i) $(-)$ Lan hau Creative Commons Aitortu-EzKomertziala-LanEratorririkGabe 4.0 Nazioartekoa

lizentzia baten mende dago 


\section{SARRERA}

Minbizian, zelulen kontrolik gabeko proliferazioa gertatzen da, eta askotan zelulak inguruko ehunak inbaditzeko gaitasuna daukate, metastasia sortuz. Gaur egun, minbiziaren tratamendu ohikoenak kimioterapia, erradioterapia eta ebakuntza dira, baina, hala ere, askotan hiru tratamendu horiek ez dira nahikoak minbiziari aurre egiteko. Horregatik, tratamendu-teknika berriak ikertzen ari dira, pertsona bakoitzarentzat espezifikoak izango direnak eta aldi berean eragin desiragaitz gutxiago sortuko dituenak. Azken urteotan CAR-T zelulak erabiliz, hau da laborategian eraldatutako pazienteen linfozito $\mathrm{T}$ infusioak erabiliz, terapia ugari martxan jarri dira tumore solido eta likidoen aurka, eta emaitza onak lortu dira.

Pertsona bakoitzaren sistema immunologikoa funtsezkoa izan daiteke minbiziari eraso egiteko, eta 2018ko Medikuntzako Nobel Saria irabazi zuten Tasuku Honjo eta James P. Allison immunologoen terapiaren premisa honako hau izan zen: minbiziaren aurkako tratamendu pertsonalizatua gaixotasun honen etorkizuna da eta CAR terapia azkar garatu den terapia da. Hala ere, estrategia berri honetarako hainbat zalantza daude argitzeke; horregatik, entsegu kliniko anitz martxan daude. Entsegu gehienak tumore hematologikoak tratatzeko garatu dira (1 [2. taula]), baina badira tumore solidoen aurkakoak ere. Esaterako, CLDN6 CAR-T terapia, 1. eta 2. fasean dagoena, martxan dago barrabiletan, obulutegian, umetokian, biriketan eta kartzinoma primarioetan frogatzeko (https://www.clinicaltrialsregister.eu). Hala ere, badira bi inmunoterapia jada pazientekin erabiltzen direnak, Tisagenlecleucel (Kymriah $\left.{ }^{\circledR}\right)$ leuzemia linfoblastiko akutuan eta Axicabtagén ciloleucel (Yescarta®) zelula B handien linfomaren aurka.

\section{CAR-T ZELULAK}

Ingelesetik ekarritako hitza da CAR-T (Chimeric Antigen Receptors in $T$-cells). Espezifikotasun handiagoa emateko diseinatuak izan diren CAR hartzaileek daramatzaten T linfozitoak dira, hots, antigorputzak ekoizten dituzten immunitate-sitemaren zelula bereziak.

\subsection{Egitura eta mekanismoa}

CAR mota guztiek gutxienez hiru atal dituzte: antigenoa ezagutzen duen zelulaz kanpoko domeinua (antigorputz batetik eratorritako zati aldakorra izaten dena, scFv), mintz arteko domeinua eta zelula barneko domeinu koestimulatzailea, $\mathrm{T}$ zelula aktibatzeaz arduratzen dena (1. irudia). 


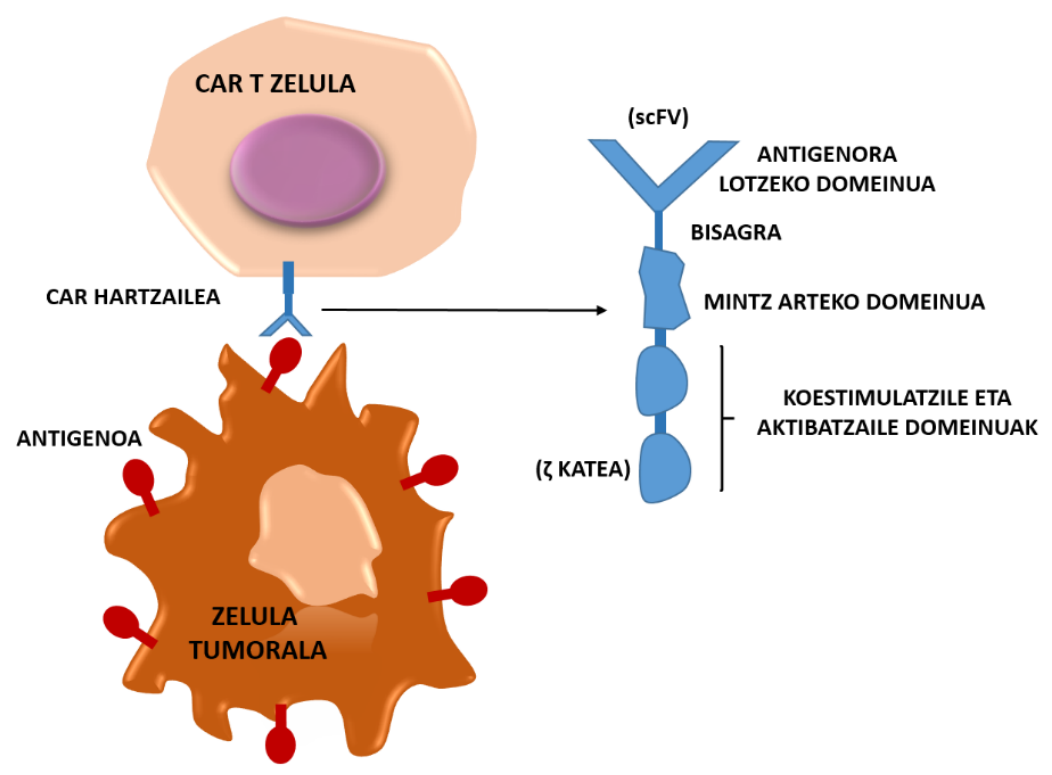

1. irudia. CAR-T zelulen egitura orokorra. (Titov A. et al., eraldatuta [8]).

Zelulaz kanpoko domeinuak antigeno tumorala ezagutzen du, eta beheranzko transdukzioa gertatzen da, seinalea mintz arteko domeinura eta domeinu koestimulatzailera bidaliz. Horrela, CAR-T zelulen aktibazioa gertatuko da, transkripzio faktoreen adierazpena hasi eta, horrekin batera, zelulen proliferazioa eta zitokinen (IL6 esaterako) askapena gertatuko dira, zitotoxikoak izanik [1]. Nahiz eta hipotetizatu izan den T zelulek zuzenean tumore-zelulak hiltzen dituztela, oraindik ez dago erabat argi zein zelula motak sortzen duen efektu antitumoral handiena.

Ektodomeinua edo zelulaz kanpoko domeinua CAR zelulen zati garrantzitsuena da; izan ere, hori da ituarekin lotzen den zatia, eta, beraz, terapiari espezifikotasuna emango diona. Zati horrek tumoreari lotutako antigenoa ezagutuko du: hain zuzen ere, tumore-zelularen mintzean adierazten den proteina konkretu bat. Proteina hau tumorearekiko espezifikoa izango da. Minbizi mota ezberdinek antigeno ezberdinak dituztenez, CAR bakoitza minbizi baten antigeno espezifikorako egina dago. Garrantzitsua izango da gaixotasun errefraktarioetan antigenoaren galerarik ez izatea eta ehun osasuntsuetako zeluletan antigenoa adierazita ez egotea. Gehien erabiltzen diren ektodomeinuak antigorputz monoklonalak izaten dira, scFv (1. irudia). Horrek kate arin bat eta kate astun bat du (oro har, B-zelulen antigorputz monoklonal bat izaten dena). scFV-a seinaleztapen-domeinu batera akoplatuta egoten da. scFV-a linfozitoaren (TCR-CD3) hartzaile konplexua, 
CD3 $\zeta$ molekularen (1. irudian) zelula-barneko domeinutik batera akoplatuta egoten da [2, 3, 4]. ScFVen ordez, NKG2D, CD16 edo Erb-B hartzaileak ere erabil daitezke.

Zelulaz kanpoko edozein antigenoren aurka zuzendutako CAR-T-ak? diseina daitezke, baina CD19 (CART-19) antigenoaren aurka zuzendutakoa da, B motako linfoma eta leuzemia linfoblastiko akutuetan (LLA) adierazten dena, oraingoz arrakasta kliniko handiena lortu duena. B zelulen espezifikoa den antigenoa (BCMA, B-Cell Maduration Antigen) da, zelula ama hematopoietikoetan adierazten ez dena eta B zelulen ezberdintzapen-prozesuan mantentzen dena. Hortaz, antigeno hau itu egokia da B zelulek sortutako neoplasietan. BCMA antigenoarekin ere hainbat ikerketa egin dira, batez ere mieloma anizkoitzaren tratamendurako. Antigeno hau plasma zelulen gainazalean aurkitu daiteke; aldiz, beste organoetako zeluletan, ez da ikusi zelula ama hematopoietikoetan eta zelula normaletan horren presentziarik; beraz, CAR-T zelulentzat oso erabilgarria izan daitekeela uste da [5].

Bisagra (hinge, spacer) IgG (IgG1 edo IgG4), IgD edo CD8aren domeinua izan daiteke, eta antigenoa ezagutzen duen zatia (scFv) mintz arteko domeinuarekin lotzea du helburu $[2,3,4]$.

Haien egitura eta produkzioa kontuan hartuta, gaur egun CAR-T zelulak laugarren belaunaldiko eboluzioan daude. Lehenengo belaunaldikoak CD3 $\zeta$ molekula bakarrik adierazten zuen, eta ez zuen arrakastarik izan saiakuntza klinikoetan [6]. Bigarren eta hirugarren belaunaldikoak CD28, 4-1BB, OX40 edo CD27 bezalako molekula estimulatzaileak zeramatzan $\mathrm{CD} 3 \zeta$-rekin batera zitokinen sintesia eta linfozitoen proliferazioa indartzeko asmoz. CAR T-zelulen laugarren belaunaldia tumore-mikroinguruaren efektu inhibitzailea gainditzeko diseinatuta dago. IL-2 eta IL-12 bezalako zitokinak jariatzearen propietate gehigarria edukitzeak badirudi emaitza hobea duela tumore solidoetan [7].

\subsection{Sortzeko prozedura}

CAR-T zelulak ekoizteko, zenbait urrats egin behar dira, eta oso garrantzitsua izango da horien kalitate-kontrola egitea protokolo osoan zehar (2. irudia).

Lehenik, pazientearen leukozitoak jaso behar dira leukaferesi bidez. Emaile baten T zelulekin egindako adopziozko immunoterapia aztertzen ari dira minbizi mota batzuk tratatzeko. Ondoren, T zelulak beste zelula guztietatik isolatu behar dira; kopuru nahikoa lortzeko, elutriadorea erabiltzen da. Behin leukaferezia eginda, CAR-a kodifikatzen duen genea linfozitoaren genoman txertatu behar da. Hori burutu ahal izateko, bi metodo bereizten dira: metodo birala (erretrobirusak) eta ez-birala (transposon/transposasa sistema) [9] 


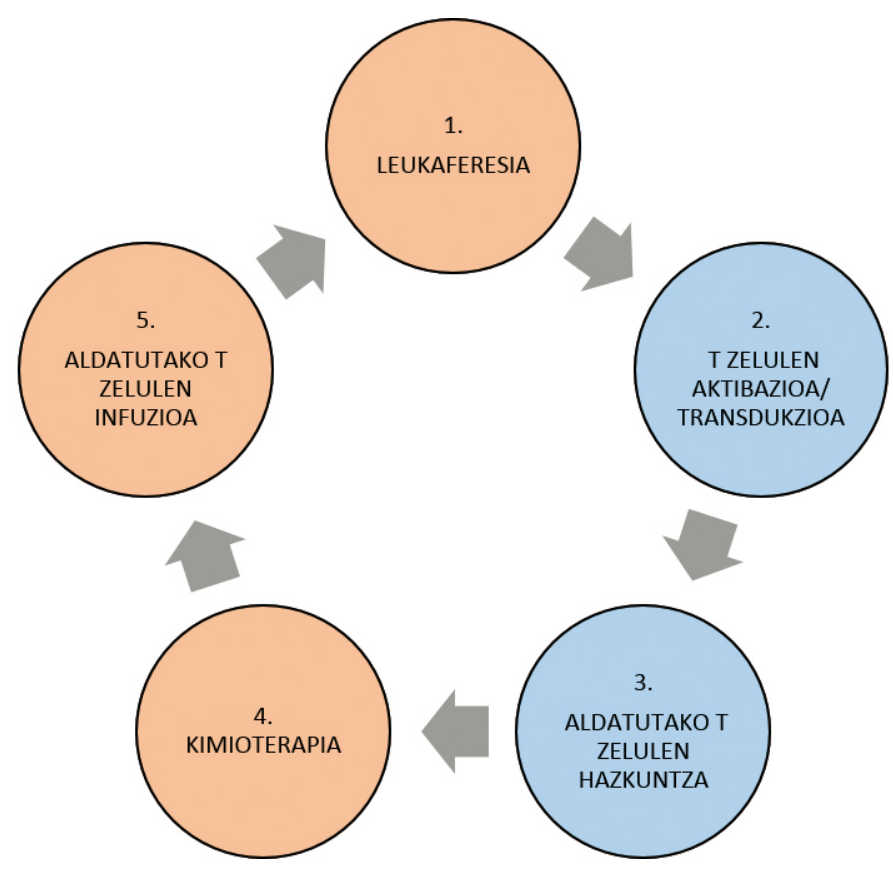

2. irudia. CAR-T zelulen produkzioaren eskema orokorra. (1) Leukaferesi bidez tratatu nahi den pazienteari T zelulak kentzen zaizkio. (2) T zelulak aktibatu egiten dira eta CAR kodifikatzen duen genea gehitzen zaio. (3) CAR-T zelulak aberastu egiten dira. (4) Pazienteak kimioterapia hartzen du linfodeplezioa jasateko. (5) CAR-T zelulen infusioa jasotzen du paziente berak. (1,4 eta 5) pazieenteetan gertatzen da (2 eta 3) laborategian (Titov A. et al., eraldatuta [8]).

Gehien erabiltzen den metodoa birala da, eta horren barruan gehien erabiltzen diren birusak, gammarretrobirusa eta lentibirusa dira. Bi bektore horiek RNA birusak dira eta, beraz, gai dira erretrotranskriptasa entzimaren bitartez DNA lortu eta DNA hori ostalariaren genoman txertatzeko. Bektore biral horiek laborategian eraldatzen dira beren patogenizitatea ahultzeko eta beharrezkoa den genea txertatzeko. Hala ere, bektore hauek alde txar bat dute: haien produkzioa zaila da eta toxikoak izan daitezke: mutagenesia gertatzeko arriskua dago [10].

Bektore biralek izan ditzaketen arazoak saihesteko asmoz, bektore ez-biralen ikerketak jarri ziren martxan, Sleeping Beauty transposon/transposasa sistema, hain zuzen ere. Transposoiek birusekin alderatuta abantaila batzuk dituzte. Alde batetik, haien produkzioa eta kalitate-kontrola errazagoa eta fidagarriagoa da. Bestetik, bektore biralek baino arrisku mutageniko gutxiago dute. Sleeping Beauty sistemak bi osagai ditu: transposoia (CAR kodifikatzen duen genea) eta transposasa entzima. Transposasa entzimak, transposoiaren alde bie- 
tan dauden errepikapenak ezagutzen ditu, DNA alde horretatik mozten du eta transposoia aske geratzen da T linfozitoen genoman txertatzeko [11, 12].

T zelulei CAR kodifikatzen duten genea txertatzean, zelulen hazkuntza martxan jartzen da beharrezkoa den zelula kopurua lortu arte. Oro har, dosi txikiak nahikoak izaten dira eraginkortasuna lortzeko, $1 \times 10^{5}-1 \times 10^{6} \mathrm{~T}$ zelula/kg-ko nahikoak izan dira entseguetan emaitza esanguratsuak lortzeko. Dosi txikiak erabil daitezke da CAR-T zelulek in vivo aurkezten duten hedapen gaitasunari esker [13].

Pazienteek CAR-T zelulen infusioa jaso aurretik linfodeplezioa jasan behar dute kimioterapia bidez. Badirudi fludabarina edo/eta ziklofosfamidarekin burututako linfodeplezioan zitokina endogeno homeostatiko batzuen mailak (IL-7 esaterako) handitu egiten direla, eta horiek CAR-T zelulen infusiorako lagungarri izan daitezkeela [13]. Linfodeplezioa jasan ondoren, pazienteek CAR-T zelulen infusioa jasotzen dute hainbat egun ezberdinetan, 4 eta 6 aste bitartean, oro har. Behin infusioa jaso dela, pazienteak monitorizatu egin behar dira tratamenduaren erantzunak ebaluatzeko eta erreakzio desiragaitzak kontrolpean mantendu ahal izateko. Toxikotasuna infusioa sartzen den egunetik kontrolatzen hasten da, eta astero ebaluatzen dira, bi hilabete igaro arte, gutxi gorabehera. Emaitzen ebaluazioa hirugarren hilabetean hasten da, eta hiru hilabetean behin neurtzen dira emaitza berriak urte bat igaro arte. Hala ere, horren ondoren ere emaitzak ebaluatzen dira, baina denbora tarte handiagoarekin, gainerako tratamendu onkologikoetan bezala [14].

\subsection{Eragin desiragaitzak}

Terapia berri honek, espezifikotasun altua dela medio, eraginkortasun ona egiaztatu du minbizi ezberdinen aurka, baina, hala ere, entsegu klinikoetan larriak izan daitezkeen eragin zehaztu dira. Toxikotasuna maila ezberdinetan banatu daiteke: tumorearen barnean sortutakoa, tumoretik kanpo, neurotoxikotasuna eta beste toxikotasun mota batzuk.

Tumore-zelularekin CAR-T zelulek kontaktu zuzena izatean gertatzen den toxikotasuna, oro har, akutua izaten da. Alde batetik, CAR-T zelulen administrazioaren ondorioz, zitokinen askapen ugaria gertatzen da, eta horrek zitokinaren askapen-sindromea (CRS, cytokine release syndrome) ekar dezake. CRSaren sintomak arinak izan daitezke: sukarra, nekea, zefaleak, artralgia, mialgia...; edo larriak ere izan daitezke, sukar altuak, hipotentsioa, organo anitzen kaltetzea...[15].

Bestalde, tumore-zelulen bat-bateko suntsipenak tumore-lisiaren sindromea ekar dezake (TLS, tumor lysis syndrome) [16]. Tumore-zelulen suntsipenak potasioaren, fosfatoen eta azido nukleikoen askapen masiboa dakar, eta organismoaren mekanismo homeostatikoek horri aurre egin ezin diotenean sortzen da. Hiperfosfatemiak hipokaltzemia sekundarioa dakar 
berekin, eta, hortaz, min neuromuskularrak, bihotz-arritmiak eta konbultsioak izateko arriskua handitzen da. Aldi berean, kaltzio fosfato kristalak prezipita daitezke hainbat organotan, batez ere giltzurrunetan, eta giltzurrun-lesio akutuak sor ditzake. Azido urikoa (azido nukleikoen metabolismotik sortua), giltzurrun barneko kristalen prezipitazioaren, giltzurruneko odol-hodien uzkurketaren, odol-jarioaren gutxipenaren eta giltzurrunaren hanturaren eragilea da. Beraz, horrek ere handitzen du giltzurrun-lesio akutua sortzeko aukera [17].

Tumoretik kanpo sortutako toxikotasuna ere kontuan izatekoa da. Izan ere, ehun osasuntsu batzuek minbizi-zelulek duten antigeno bera dute beren gainazalean, eta, hortaz, CAR-T zelulek ehun horiek erasotzen dituzte, eta zelula osasuntsuen suntsipena gertatu ohi da. Toxikotasun mota hau asko gertatzen da B linfozitoek sortutako gaitzetan, CD19 antigenoa B zelula guztien gainazaletan agertzen delako, bai zelula osasuntsuetan bai minbizi-zeluletan. Beraz, CD19 CAR-T zelulekin egindako tratamendua hastean, denboran zehar iraun dezakeen B zelulen aplasia gerta daiteke [18, 19].

Kasu gehienetan CRS pairatu ondoren neurotoxikotasuna gertatzen da; hala ere, litekeena da CRS eman gabe pairatzea. Manifestazio kliniko nagusiak entzefalopatiak, apraxia, dardarak, konbultsioak eta edema zerebrala dira. Toxikotasun mota honen fisiopatologia ez da oraindik ondo ezagutzen, baina badirudi hesi hematoentzefalikoaren alterazio baten ondorioz izan daitekeela, zitokina maila altuek sortua. IL-2, IL-2R, IFN- $\gamma$, IL-6 eta IL-6R erlazionatu dira neurotoxikotasunaren sorrerarekin. Gainera, hesi? hematoentzefalikoaren alterazioaren ondorioz, neurotransmisoreen askapenaren erregulazioa kaltetuta ikus daiteke, glutamato eta azido kinolinikoarena, esaterako. Zitokinek mikrogliak, monozitoak eta makrofagoak aktibatzen dituzte, eta haiek azido kinolinikoa askatzen dute nerbio-sistema zentralaren erantzun inflamatorioan neurotoxikotasuna pairatzen duten pazienteetan. Azido kinolinikoak eta TNF- $\alpha-k$, biak batera, glutamatoaren askapena bultzatzen dute, honen mailak igoz eta, hortaz, zitotoxikotasuna bultzatuz. Hala ere, ekintza-mekanismoa oraindik ez da guztiz ezagutzen eta ikerketa gehiago behar izango dira hori ondo ulertzeko [20,21, 22].

Beste toxikotasun mota batzuk ere gertatzen dira. Berez, $T$ zelulen administrazioa egin baino lehen, pazienteari tratamendu immunokentzaile bat egitea gomendatzen da, T zelulek egoera horretan tumorearen aurkako eraginkortasun handiagoa dutela ikusi baita. Hala ere, horrek desio ez ditugun eraginak izan ditzake; izan ere, linfodeplezioaren ondorioz, anemia, koagulopatiak edo sepsi neutropenikoa jasateko arriskua handitu egiten da [22].

Bestealde, terapia honetan erabiltzen diren antigorputzen gehiengoa saguetatik datozen antigorputz monoklonalak dira, erreakzio anafilaktikoak sortu dezaketenak. Gizakietatik datozen antigorputzak erabiltzea gomendatzen da toxikotasun mota hau neurri batean saihestu ahal izateko [23]. 
Bukatzeko, genotoxikotasuna dago. Erretrobirusak eta lentibirusak bektore moduan erabiltzea $\mathrm{T}$ zelulen espresioa errazteko pentsatuak izan ziren. Hala ere, bektore horiek erabiltzeak gertakizun onkogenikoen sorrera bultza dezake. Gaur egunera arte, ez da honelako toxikotasunik ikusi CAR-T zelulen erabilerarekin; kontuan hartu beharko den parametroa izango da minbiziak tratatzeko momentuan [10].

\section{APLIKAZIOA MINBIZI SOLIDOETAN}

Gaixotasun hematologikoetarako, leuzemia linfoblastiko akutua eta linfoma kasuetan bezala [24], CAR-T zelulen terapia ezarrita egon arren, tumore solidoetan dauden terapiaren erabilera eztabaidagarria da oraindik. Izan ere, immunoterapiatik ihes egin dezaketen tumore gehienak solidoak izan ohi dira, hau da, oro har tumore horiek populazio anitzez eta antigeno aldakorrak adierazten dituzten zelulez osatuta daude $[25,26]$. Tumore zelulek immunitate sistemari ihes egiteko mekanismoen barietate handia daukate, ezagupena, antigenoaren mutagenesia edo galera, zitokina inmuno-inhibitzaileen jariapena, zelula immunogutxitzaileak erreklutatzea [27]. Gainera, tumore solidoetan, CAR-T terapia mugatua dago, tumorearen mikroinguruneak funtzio immunoezabatzailea sor dezakeelako zelulak erakarriz, hala nola $\mathrm{T}$ zelula erregulatzaileak, tumoreekin erlazionatutako makrofagoak eta mieloide jatorriko zelula ezabatzaileak. Guztiek parte har dezakete CAR-T zelulen inhibizioan, CAR-T zelulekin egindako terapien onurak mugatuz, tumorearen garapena bermatuz [28].

Hala ere, badaude CAR-T bidezko estrategia terapeutiko itxaropentsu ugari tumore solidoetan. Azken entseguek tumore solidoen zelulek adierazten duten gainazaleko proteinen arabera diseinatu dira. Tumore solidoetan CAR-T zeluletan oinarritutako estrategia terapeutiko itxaropentsu ugari daude. Azken saiakuntzak tumore solidoen zelulek mintzean adierazten duten proteinen arabera diseinatu dira: esaterako, giza gainazaleko proteinepidermisekoa hazkuntza-faktore 2aren hartzailea (HER2), digangliosidoa (GD2), antigeno karkarinoembrikoa kartzinoenbrionarioa (CEA), mesotelina eta fibroblastoak aktibatzeko proteina (FAP), besteak beste. Lehenengo bi antigenoekin (HER2 eta GD2) egindako entsegu klinikoek bakarrik eman dituzte emaitza positiboak [29]. Proba bakar batean lortu da neuroblastoma erabat murriztea GD2-CAR erabiliz [30]. HER2-CAR erabiliz sarkoman eta biriketako zelula ez txikiko minbizi aurreratuetan gaixotasunaren egonkortzea edo tratatutako pazienteen erantzun partziala erakutsi da $[31,32]$.

CAR-T terapia arrakastatsua izan da koloneko minbiziaren eredu aurreklinikoetan edo fase goiztiarreko saiakuntza klinikoetan. Itu izan daitekeen 
molekula ugari ikertzen ari dira [33]. Baina 1. faseko saiakuntza klinikoetan CART72 zelulak erabiltzen dira. Eraldatutako linfozito horiek tumoreari lotutako glikoproteina (Tag) -72ra zuzenduta daude, eta zeluletan CD3-zeta seinaleztapena pizten dute.

Immunoterapiak CAR-T zelulekin duen arazo nagusietako bat da erantzun iraunkorra koloneko minbizia duten pazienteen azpitalde txiki batentzat baino ez dagoela eskuragarri. Terapia egokia izango litzateke CAR-T zelulen terapia kontrol-inhibitzaile berriekin edo antigorputz monoklonalekin konbinatzea.

\section{ONDORIOAK}

$\mathrm{T}$ zelulen terapia azken urteotan garatu da. Metodo horrekin gaixotasun hematologikoak tratatzeko modua aldatuz doa, eta tumore solidoak tratatzeko aukerak ikusarazten dizkigu. Tumore solidoetarako CAR-T zelulen lehen saiakuntzek leuzemia-saiakuntzetan behatutako arrakasta bera erakutsi ez duten arren, tumore solidoetan behatutako oztopo ugariak hobeto ulertzeak aurrerapenak ekarriko ditu CAR ingeniaritzan eta saiakuntza klinikoen diseinuan.

Ikerketa traslazionalaren helburu nagusietako bat da leuzemiatik haragoko minbizietan erabiliko diren CAR-T zelulen espezifikotasuna, eraginkortasuna eta segurtasuna hobetzea. Tumore-zelularen gainazaleko antigeno benetan espezifikoak identifikatu behar dira, eta erabakigarria da hilgarriak izan daitezkeen ustekabeko toxikotasunak arintzeko mekanismo eraginkorrak ezartzea. Gainera, tumorearen heterogeneotasunarekin, tumorearen immunogutxitzearekin eta $\mathrm{T}$ zelulen zirkulazio eta iraunkortasun faltarekin lotutako arazoak konpontzea eta tumore solidoen terapiaren eraginkortasuna hobetzea lantzen ari dira.

Neoplasia hematologikoetan CAR terapiaren arrakasta sinesgarria eta melanoma-tumoreen linfozito infiltratzaileen infusioen arrakasta CAR terapiaren garapena bultzatzen ari dira, tumore solidoetan antzeko eraginkortasuna erakuts dezaketenak. CAR zelulak genetikoki manipulatzeko gaitasunak aldaketa eta hobekuntza gehigarrietarako aukera ia mugagabeak ematen ditu, eta, beraz, etorkizunean arrakasta izateko itxaropen handia ematen du.

Azken datuek erakusten dute CAR-T zelulen terapia erabilgarria izan daitekeela koloneko, pankreako, urdaileko minbizian edo minbizi hepatobiliarrean. Horrek azterketa gehiago egiteko atea ireki du, gainera beste terapia batzuekin batera probatzen ari da $(\mathrm{CPB} /$ check pint blockade agentekin batera esaterako anti-PD1, [34]). Nahiz eta lan asko egin behar den, minbiziaren aurkako immunoterapiak emaitza itxaropentsuak ekarriko ditu. 


\section{BIBLIOGRAFIA}

[1] MAUS MV, GRUPP SA, PORTER DL, JUNE CH. 2014 «Antibody-modified T cells: CARs take the front seat for hematologic malignancies». Blood. 123[17], 2625-2635.

[2] ABATE-DAGA D, DAVILA ML. 2016 «CAR models: next-generation CAR modifications for enhanced T-cell function». Molecular Therapy - Oncolytics; 3[C], 16014.

[3] GELDRES C, SAVOLDO B, DOTTI G. 2015 «Chimeric antigen receptorredirected T cells return to the bench». Seminars in Immunology. 28[1], 3-9.

[4] JOHN S. BRIDGEMAN, ROBERT E. HAWKINS, ANDREAS A. HOMBACH, HINRICH ABKEN, DAVID E. GILHAM. 2010. «Building Better Chimeric Antigen Receptors for Adoptive T Cell Therapy». Current Gene Therapy, 10[2], 77-90.

[5] ATRASH S, BANO K, HARRISON B, ABDALLAH A. 2020. «CAR-T treatment for hematological malignancies». Journal of Investigative Medicine, 68[5], 956-964.

[6] SUN S, HAO H, YANG G, ZHANG Y, FU Y. 2018. «Immunotherapy with CAR- Modified T Cells: Toxicities and Overcoming Strategies». Journal of Immunology Research, 2018, 1-10.

[7] MAUDE S, BARRETT DM. 2016. «Current status of chimeric antigen receptor therapy for haematological malignancies». British Journal of Haematology, 172[1], 11-22.

[8] TITOV A, VALIULLINA A, ZMIEVSKAYA E, ZAIKOVA E, PETUKHOV A, MIFTAKHOVA R, et al. 2020. «Advancing CAR T-Cell Therapy for Solid Tumors: Lessons Learned from Lymphoma Treatment». Cancers, 12[1], 125.

[9] NAING A, HAJJAR J. 2020. Immunotherapy. 3rd ed. Springer Nature, Switzerland.

[10] WANG X, RIVIÈRE I. 2016. «Clinical manufacturing of CAR T cells: foundation of a promising therapy». Molecular Therapy-Oncolytics, 3[C], 1-7.

[11] PAHLE J, WALTHER W. 2016. «Vectors and strategies for nonviral cancer gene therapy». Expert Opinion on Biological Therapy, 16[4], 443-461.

[12] HUDECEK M, IZSVÁK Z, JOHNEN S, RENNER M, THUMANN G, IVICS Z. 2017.«Going non-viral: the Sleeping Beauty transposon system breaks on through to the clinical side». Critical Reviews in Biochemistry and Molecular Biology, 52[4], 355-380.

[13] ASCIERTO PA, STRONCEK DF, WANG E. 2015. Developments in T Cell Based Cancer Immunotherapies. 1st ed: Springer International Publishing, Switzerland.

[14] GEE AP. 2018. «GMP CAR-T cell production». Best Practice \& Research Clinical Haematology, 31[2], 126-134.

[15] BRUDNO JN, KOCHENDERFER JN. 2019. «Recent advances in CAR Tcell toxicity: Mechanisms, manifestations and management». Blood review, 34, 45-55. 
[16] HOWARD SC, JONES DP, PUI C. 2011. «The Tumor Lysis Syndrome». The New England Journal of Medicine, 364[19], 1844-1854.

[17] NEELAPU S. 2019. «Managing the toxicities of CAR T-cell therapy». Hematological Oncology, 37[S1], 48-52.

[18] BONIFANT L, JACKSON HJ, BRENTJENS RJ, CURRAN KJ. 2016. «Toxicity and management in CAR T-cell therapy». Molecular Therapy Oncolytics, 3[C], 16011.

[19] KALAITSIDU M, KUEBERUWA G, SCHÜTT A, GILHAM DE. 2015. «CAR T-cell therapy: toxicity and the relevance of preclinical models». Immunotherapy, 7[5], 487-497.

[20] RIVERA AM, MAY S, LEI M, QUALLS S, BUSHEY K, RUBIN DB. 2020. «CAR T-Cell-Associated Neurotoxicity: Current Management and Emerging Treatment Strategies». Critical care nursing quarterly, 43[2], 191-204.

[21] ATRASH S, BANO K, HARRISON B, ABDALlAH A. 2020. «CAR-T treatment for hematological malignancies». Journal of Investigative Medicine,68[5], 956-964.

[22] YANG X, WANG G, ZHOU J. 2019. «CAR T Cell Therapy for Hematological Malignancies». Current medical science, 39[6], 874-882.

[23] HALLAJ S, MESHKINI F, CHALESHTARI M, GHORBANI A, NAMDAR A, SOLEIMANPOUR H. 2019. «Conjugated CAR T cell one step beyond conventional CAR $\mathrm{T}$ cell for a promising cancer immunotherapy». $\mathrm{Ce}$ llular Immunology, 345, 1-14.

[24] TOMULEAS C, FUJI S, BERCE C, ONACIU A, CHIRA S, PETRUSHEV B, MICU W.T, MOISOIU V, OSAN, C, CONSTANTINESCU C. 2018. «Chimeric Antigen Receptor T-Cells for the Treatment of B-Cell Acute Lymphoblastic Leukemia». Frontiers in Immunology, 9 [239], 1-14.

[25] MCGRANAHAN N, SWANTON C. 2015. «Biological and therapeutic impact of intratumor heterogeneity in cancer evolution». Cancer Cell, 27, 15-26.

[26] O'ROURKE DM, NASRALLAH MP, DESAI A, MELENHORST JJ, MANSFIELD K, MORRISSETTE JJD, et al. 2017. «A single dose of peripherally infused EGFRvIIIdirected CAR T cells mediates antigen loss and induces adaptive resistance in patients with recurrent glioblastoma». Science Translational Medicine, 9, 1-15.

[27] DUNN GP, OLD LJ, SCHREIBER RD. 2004. «The three Es of cancer immunoediting». Annual Review of Immunology, 22, 329-360.

[28] ANDERSON KG, STROMNES IM, GREENBERG PD. 2017. «Obstacles posed by the tumor microenvironment to T cell activity: A case for synergistic therapies». Cancer Cell, 31, 311-325.

[29] GILL, S.; MAUS, M.V.; PORTER, D.L. 2016. «Chimeric antigen receptor T cell therapy: 25years in the making». Blood, 30, 157-167.

[30] LOUIS C.U, SAVOLDO B, DOTTI G, PULE M, YVON E, MYERS G.D, ROSSIG C, RUSSELL H.V, DIOUF O, LIU E, et al. 2011. «Antitumor ac- 
tivity and long-term fate of chimeric antigen receptor-positive $\mathrm{T}$ cells in patients with neuroblastoma». Blood, 118, 6050-6056.

[31] AHMED, N.; BRAWLEY, V.S.; HEGDE, M.; ROBERTSON, C.; GHAZI, A.; GERKEN, C.; LIU, E.; DAKHOVA, O.; ASHOORI, A.;CORDER, A.; et al. 2015. «Human Epidermal Growth Factor Receptor 2 [HER2] -Specific Chimeric Antigen Receptor - Modified T Cells for the Immunotherapy of HER2-Positive Sarcoma». Journal of Clinical Oncology, 33, 1688-1696

[32] FENG,K.; GUO, Y.; DAI, H.; WANG, Y.; LI, X.; JIA, H.; HAN, W. 2016. «Chimeric antigen receptor-modified $\mathrm{T}$ cells for the immunotherapy of patients with EGFR-expressing advanced relapsed/refractory non-small cell lung cancer». Science China Life Sciences, 59, 468-479.

[33] HEGE, K.M.; BERGSLAND, E.K.; FISHER, G.A.; NEMUNAITIS, J.J.; WARREN, R.S.; MCARTHUR, J.G.; LIN, A.A.; SCHLOM, J.; JUNE, C.H.; SHERWIN, S.A. 2017. «Safety, tumor tracking and immunogenicity of chimeric antigen receptor [CAR]-Tcells specific for TAG-72 in colorectal cancer». Journal for Immunoherapy of Cancer, 5, 1-14.

[34] GROSSER R., CHERKASSKY L, CHINTALA,S. ADUSUMILLI P. 2020. «Combination Immunotherapy with CAR T Cells and Checkpoint Blockade for the Treatment of Solid Tumors» Cancer Cell.36[5], 471-482. 